\title{
FUNDAMENTAL STUDIES ON THE SCREENING TEST OF CHEMICAL AGENTS FOR MURINE LEPROSY
}

\section{PART 1. ON THE STRAIN, INOCULATED SITE AND DOSIS}

\author{
Shinji Nishimura \\ Leprosy Laboratory, Research Institute for Microbial Diseases, Osaka University
}

\section{Kenji Iwasa}

(Dermatrogical Department of Osaka University Medical School)

It is most desirable for the screening test of chemical agents to abbreviate the experiment process and to provide the simple standards to judge the results. The following experiments were carried out to find out the murine bacillus strain, inoculation site and dosis which can satisfy those conditions. All the experiments were done with mice.

1) Bacillus Strain: By subcutaneous inoculation, the virulences of Kumamoto, Hawaiian, Keishicho and Fukuoka strains were compared.

The results presented that Fukuoka strain is weaker, and the other three strains have the similar pathogenity. (Tab. 1, 2, 3, 4)

2) Inoculation Site: Subcutaneous inoculation produced leproma at the site in an early period which can be observed exactly. (Tab. 1, 2)

Intraperitoneal and intravenous injections give a rise to the disease in various organs after long while. The predilected organ can not be found and the results are shown by bacillus distribution index and not by a practical standard. (Tab. 5, 6, 7, 8)

3) Inoculation Dosis: $0.2 \mathrm{ml}$ of $10^{2} \sim 10^{4}$ diluted leproma suspension gives a rise to the disease 2 or 3 months after subctaneous inoculation. When the suspension decreases to $10^{6} \sim$ $10^{8}$, the longer period is necessary to produce the disease.

By intraperitoneal injection, $0.5 \mathrm{ml}$ of $\times 50$ diluted suspension produced the disease after $3 \sim 4$ months. 3 months after intravenous injection $0.2 \mathrm{ml}$ of $10^{2}$ suspension gives a rise to visible changes in the $30 \%$ of the viscera. It will take longer period to recognize lesions in all cases.

The above results ead us to conclude that the most adequate experiment is to be carried out with Hawaiian strain on account of its international value by subcutaneous inoculation in the dosis of $0.2 \mathrm{ml}$ of $10^{2} \sim 10^{4}$ diluted suspension, and to observe the development for 3 months.

\section{鼠癩化学療法棛の Screening Test に関する 基礎的実験（其の 1 ）} 鼠癩菌株の選択站に接種部位と菌量の検討

大阪大学微生物病研究所頙研究部

西 村 真 二
大阪大学医学部皮虐科必尿器科教室
竖 佳 賢 二
(昭和 30 年 5 月 27 日受稿)


鼠瀨化学療法鼡をマウスで Screening するには，㿤験 の期間を出来るだけ短かく，そして簡単確実な基㔼のも とに，てきぱきと判定して行くことが最も望ましいの でとのような目的に合致した一つの実験方法を作り上 ゲたいと考えて，その基礎的実験の一部として，先ず使 用する鼠癩菌株の選択, 接種部位, 滥に, 接種菌量など について検討を行つた。

\section{I 鼠癩菌株の選択}

結核菌 H 37RV 株が，現在抗結核風の実験に標隼株と して広く用いられているよらに, 抗鼠瀨剤の試験に打い ても亦，標凖株の選択が必要であるととは言らあでもな い。此の場合条件として最も重要なととは， Virulence の強いもの, 即ち少量の菌によつて速かに発症するもの でなければならないととでもる。

今回の実験に用いた菌株は，日本に於ける代表的菌株 として, わが教室に継代保存していた 3 株と, 最近アメ リカより贈られた株，棓 4 株で，その由来は次の通りで ある。

\section{使用菌株の由来}

熊本株：熊本市に於いて，太田原，市原が発見，ラ ットへ継代したもの，1942年北研渡辺義政博士を経て， 当研究所へ分与されたもので，1952年4 月以降マウスへ 継代。

福岡 1 号株：福岡市にて, 戸田，占部が検出，ラッ トへ継代したもの，1945年占部教授より当研究所へ分与 された株，1952年10月以降マウスへ継代。

警視庁株 :東京警視庁細菌検査所仿いて，内田(三) が発見，ラットへ継代したもの. 東北大抗研佐藤教授の もとに保存された株を1953年. 真山助教授より分与され 同年 9 月よりマウスへ継代。

ハワイ株：アメリカ合衆国及び，南米方面で多く用 いられている株で，1952年11月，Harvard 大学 Hanks 博士からマウス継代のま贈られたもの．爾来マウスへ 継代。

\section{実験方法}

a) 菌乳凧の作り方

各菌株ともマウス継代 3 代以上のもの，即ちマウス剛 化株を使用し，皮下接種3 4月の新鮮なLeproma を摘出 して用いた。この場合マウスの個体によつて. Leproma 中の鼠謴菌数に多少の相違することを考慮し.これを出 来る限り均一にするため, 各株とも3〜4匹分の Leproma を摘出混合した。

脂肪組織 や而液成分を除いた上，0.1g を敩密に科量
し. 滅菌乳鉢にて丁寧に磨研し徐々に生理的食塩水を注

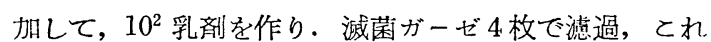
を原液とする。

そして此の際，菌株毎に乳凨中の菌数を計算して打く ととにした。

b) Leproma 乳刱中の菌数計算法

スメヤーによる牛乳中の細菌数検查法を援用した。原 理は，纂本をマイクロピペットにて 0.01cc 吸取り。よ く清拭したスライド上 $1.0 \mathrm{~cm}^{2}$ の広さに平等に祭布し， 擥卵器 $\left(37.0^{\circ} \mathrm{C}\right)$ にて乾懆後. チールネルセン法で染 色。顕微鏡は視野の直径を ${ }^{20.5} / 10$ ( $\mathrm{mm}$ に調節して扔くと， 1 視野の面稳が度 13000 に当るので，乙の拡大によつて 1 視野中に見出される菌数を数えあげれば，検体 $1 \mathrm{ml}$ 中の菌数は次式によつて簡単に算出される。

平均数 $\times 3000 \times 100=$ 可検液 $1 \mathrm{ml}$ 中の菌数

この場合，載物硝子上 3 ヶ所に㙦抹し，各々について 30 視野以上の菌数を平均するとと。

站に，整抹を平等に，かつ，染色時の水洗などを慎重 に行らととが䛊差を尠くする上に重要なととである。可 検液の濃度は, $10^{3} \sim 10^{4}$ 液が適当で, $10^{2}, 10^{5}$ 液は過 多或は過少で計算には却つて不便である。

c）使用マウスと接種部位

第 1 次実験ではNA 1 系，NA 8 系，マウス計 120 匹を 第 2 次実験では, NA 1 采, NA 2 采, S 417 系, 雑系、 ウス計 357 匹を用い， 字共に体重 $18 \mathrm{gr} \pm 2 \mathrm{gr}$ すのを 使用した。注射部位はこの場合，下腹部皮下に一定した。

d）接種菌量

Leproma 乳剤が濃厚に過ざる場合は，含菌量と共に組 織成分子多量となるため，乙の様な菌体以外の成分によ る発定への影響を出来るだけ取除くためと，今一つは， 発症力の比較に便利なよりに, $10^{2}, 10^{3}, 10^{4}, 10^{6}$, $10^{7}, 10^{8}$, 乳風を $0.2 \mathrm{cc}$ づつ接種した。乳刜中の菌数を 揚げると次のようである。

菌株第 1 次実験 $\times 1000$ 第 2 次実験 $\times 1000$ 液 $0.2 \mathrm{ml}$ 中の菌数 夜 $0.2 \mathrm{ml}$ 中の菌数

熊本株 $\quad 996,000 \quad 4116,000$

ハワイ株 $\quad 768,000 \quad 4122,000$

福岡株 $702,000 \quad 1668,000$

警視庁株 $\quad 702,000 \quad 3960,000$

e）成績判定法（写真参照）

皮下接種の判定法としては，局所に生じた Leproma の拡がりと. 解剖時の淋巴腺, 内臓の菌分布を指標とし た。

Leproma の㹡がりによハ判定は次のよらに表示した。 
拡がり 触 診記号 指数

$1 \sim 10 \mathrm{~mm}^{2} \cdots \cdots \cdot$ 痕跡 栗粒大 $\cdots \cdots+\cdots \cdots \cdots \cdot 1$

$11 \sim 30 " \cdots \cdots$ 半 米粒 大 $\cdots \cdots \cdots+\cdots+\cdots \cdots \cdot \cdot 2$

$31 \sim 70 " \cdots \cdots$ 米 粒 大……………... 3

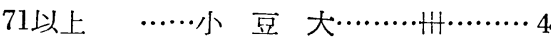

淋巴腺は，左右の鼠嗘腺，腋䆚腺，顎下腺を,内歲は， 肺，肝．脾について病変の最も著しい部分の割面をスタ ムプスメヤーとし，チールネルセン染色を行つて鏡検し た。との場合弱拡大にて細胞内に増殖せる菌集団を目標 に検索. 全視野に於けるグロビー数を算え上げ，菌集団
を認めない場合は，強抎大を以て孤立菌を探索するよう にした。成績の表示は次の標淮に拠つた。

$\begin{array}{ccc}\text { 菌集団数 } & \text { 記号 } & \text { 指数 } \\ \text { 孤立菌のみ } & + & 1 \\ 1 \sim 10 & + & 2 \\ 11 \sim 50 & H & 3 \\ 51 \sim 100 & H & 4 \\ 101 \text { 以上 } & \infty & 5\end{array}$

\section{実験成績}

a）Lepromaの㹡がりについて見た成績（表 1.2）

Table 1. Comparative Development of Leproma-Strains in Subcutis

(The 1 st Experiment)

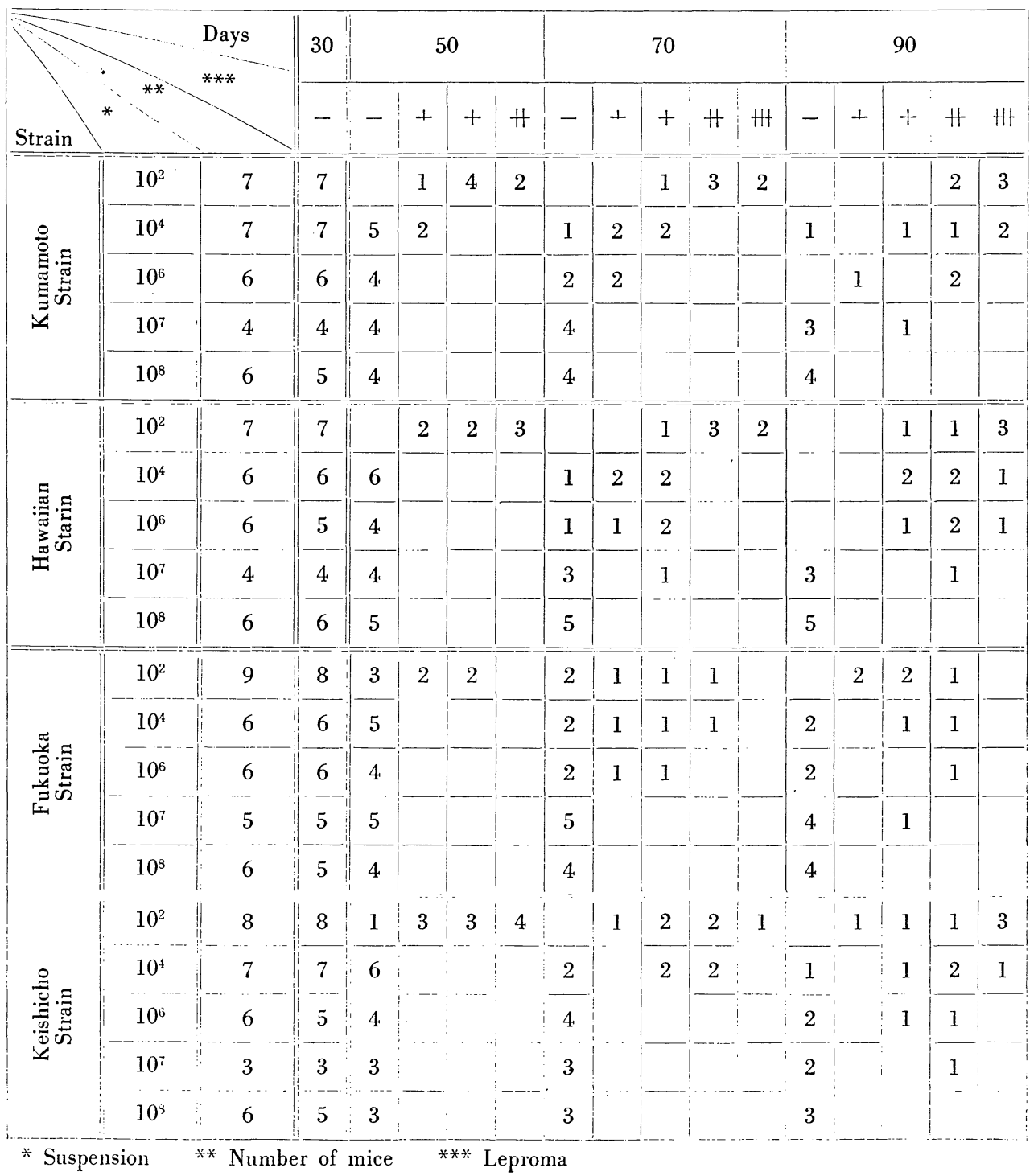


Table 2 Comparative Development of Leproma-Strain in Subcutia (The 2 ndExperiment)

\begin{tabular}{|c|c|c|c|c|c|c|c|c|c|c|c|c|c|c|c|c|c|}
\hline & & & 60 & & & & & & & 120 & & & & & 150 & & \\
\hline Strain & & & - & - & $\perp$ & + & H & - & $\perp$ & + & H & HH & - & + & + & $H$ & HH \\
\hline & $10^{4}$ & 26 & 20 & 4 & 5 & 9 & 2 & & 1 & 5 & 8 & 6 & & & 1 & 2 & 10 \\
\hline 范.E & $10^{6}$ & 20 & 20 & 18 & & 1 & & 8 & 6 & 2 & 1 & 2 & & 1 & 5 & 1 & 2 \\
\hline$\underline{g}$ & $10^{7}$ & 26 & 26 & 26 & & & & 15 & 3 & 4 & 2 & 1 & 2 & 7 & 3 & 6 & 3 \\
\hline & $10^{8}$ & 21 & 21 & 21 & & & & 19 & 1 & & & & 4 & 5 & 2 & 1 & 1 \\
\hline & $10^{4}$ & 19 & 19 & 5 & 5 & 3 & 4 & 1 & 2 & 2 & 6 & 6 & & 2 & 1 & 3 & 6 \\
\hline$\Xi$ & $10^{6}$ & 21 & 21 & 19 & & 1 & & 11 & 2 & 4 & 4 & & 1 & 3 & 3 & 5 & 4 \\
\hline 㞼苟 & $10^{7}$ & 26 & 26 & 23 & & & & 17 & 2 & 2 & 1 & 1 & 7 & 6 & 2 & 5 & \\
\hline & $10^{8}$ & 21 & 21 & 18 & & & & 13 & 1 & 2 & & & 6 & 4 & 3 & & 1 \\
\hline & $10^{4}$ & 18 & 18 & 15 & 1 & 1 & 1 & 2 & 5 & 5 & 4 & 2 & & & 5 & 4 & 4 \\
\hline 亲. & $10^{\circ}$ & 18 & 18 & 18 & & & & 16 & 1 & 1 & & & 3 & 5 & 4 & 2 & 1 \\
\hline 声 & $10^{7}$ & 24 & 24 & 23 & & 1 & & 15 & 2 & 4 & & & 8 & 3 & 4 & 3 & 2 \\
\hline & $10^{8}$ & 20 & 20 & 20 & & & & 18 & 1 & & & & 11 & 7 & 1 & & \\
\hline & $10^{4}$ & 18 & 18 & 9 & 5 & 2 & 2 & 1 & 1 & 5 & 5 & 6 & & & 1 & 5 & 6 \\
\hline$\stackrel{ْ}{\stackrel{D}{0} .}$ & $10^{6}$ & 20 & 20 & 16 & 1 & 2 & & 10 & 1 & 5 & 2 & 1 & 1 & 2 & 7 & 5 & 1 \\
\hline 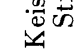 & $10^{7}$ & 25 & 25 & 24 & & & & 17 & 5 & 1 & 1 & & 3 & 8 & 7 & 3 & 1 \\
\hline & $10^{8}$ & 19 & 19 & 19 & & & & 17 & 1 & 1 & & & 5 & 7 & 4 & & \\
\hline
\end{tabular}

\footnotetext{
* suspension ** Number of mice *** Leproma
}

この表で見られる如く，102乳刋を接種したものでは， 熊本. ハワイの雨株が略々同等に，警視庁株もとれと大 差なくただ福岡株のみが.かなり颃くれて発症した。 $10^{4}$ では, 第 1 次，第 2 次実験を通じて，熊本>ハワィ >警規庁>福岡の順位を示したが. 上位の 3 者間には, 著しい差がみられなかつた。106 は第 1 次実験では， 八 ワイ>熊本>福岡>警視庁，第 2 次では，警視预>熊本 >ハワイ>福闭となつた。1 $10^{8}$ では警視庁>熊本〉ハワ イ>福岡の順位となつた。以上のような発应度からみ て, 熊本. ハワィ,警視庁の 3 株間には, Virulence に殆 ど差を認めないが, 福岡株はこれらに比較して稍々弱株 のよらである。ただこのよらな慢性肉芽増殖を主徴とす る鼠瀨などでは, 接種菌量が少量になればなる程, 被接 種マウスの個体差が，い上小上強く現われ，その判定が むづかしいので, 結同多数のマウスを使用して，その平 均值を求め正晀を期するようにした。 b）菌の分布度から見た成績（第 $3 ， 4$ 表参照）

このように接種菌量別に区分して表示したのは，菌接 種量の多夏によつて既に当初から各臓器への菌分布数が 違らので, その縅器内での増殖量や原発巣からの転移を 比較するためには，どうしても接種菌量を一定にして招 く必要があるからである。

第 3 表は 4 株の菌を接種菌毎に，104，106，107乳刜に 分けて, それぞれ淋巴腺と臓器の菌分布度を比較したも ので，第 4 表はその成績の総括である。即ち，104では， 計54匹のマウスについて鼠蹊腺, 脑窝腺, 顎下腺, 肺, 肝, 脾と6 個所から標本を作つて計 324 個を調べたとと ろ, その内 160 個所, 平均 $49.4 \%$ 菌陽性でむつた。そ して，乙の指数が計 402 となり，マウス一尼当りの平均 指数 7.4を示した。ところで，この平圳指效よりも上位 にむるのは, 警視庁, 熊本, 八ワイで福葥はそれ以下を 示している。次に $10^{6}$ についてみるに, 菌陽性数, 平均 
Table 3 Comparative Distribution of Bacillus-Strains in Various Organs (1)

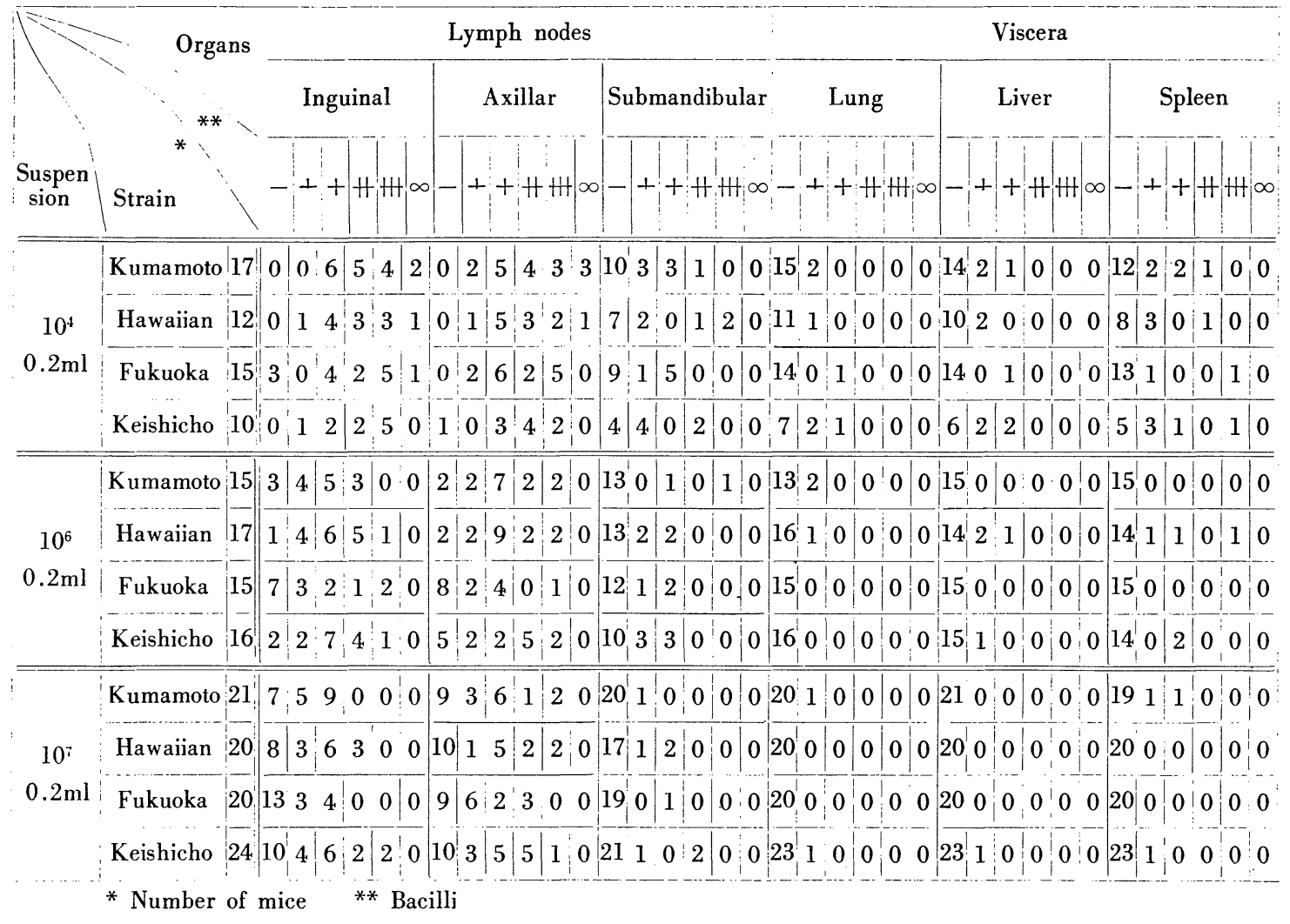

Table 4. Comparative Distribution of Bacillus-Strains in Various Organs (2)

\begin{tabular}{|c|c|c|c|c|c|c|c|}
\hline $\begin{array}{l}\text { Suspen } \\
\text { sion }\end{array}$ & Strain & $\begin{array}{l}\text { Number } \\
\text { of mice }\end{array}$ & $\begin{array}{l}\text { Number of } \\
\text { sections } \\
\text { examined }\end{array}$ & $\begin{array}{l}\text { Number of } \\
\text { Organs in } \\
\text { which bacilli } \\
\text { were found }\end{array}$ & $\begin{array}{c}\text { Average } \\
\text { number of } \\
\text { positive sections }\end{array}$ & $\begin{array}{c}\text { Index of } \\
\text { average } \\
\text { number of } \\
\text { positive sections }\end{array}$ & $\begin{array}{l}\text { Index of } \\
\text { the average }\end{array}$ \\
\hline \multirow{5}{*}{$\begin{array}{c}10^{4} \\
0.2 \mathrm{ml}\end{array}$} & Kumamoto & 17 & 102 & 51 & 50.0 & 131 & 7.7 \\
\hline & Hawaiian & 12 & 72 & 35 & 48.5 & 90 & 7.5 \\
\hline & Fukuoka & 15 & 90 & 37 & 41.1 & 99 & 6.6 \\
\hline & Keishicho & 10 & 60 & 37 & 61.6 & 82 & 8.2 \\
\hline & Total & 54 & 324 & 160 & 49.4 & 402 & 7.4 \\
\hline \multirow{5}{*}{$\begin{array}{c}10^{6} \\
0.2 \mathrm{ml}\end{array}$} & Kumamoto & 15 & 90 & 29 & 32.2 & 58 & 3.8 \\
\hline & Hawaiian & 17 & 102 & 42 & 41.1 & 88 & 5.2 \\
\hline & Fukuoka & 15 & 90 & 18 & 20.0 & 38 & 2.6 \\
\hline & Keishicho & 16 & 96 & 33 & 34.4 & 75 & 4.7 \\
\hline & Total & 63 & 378 & 122 & 32.3 & 259 & 4.1 \\
\hline \multirow{5}{*}{$\begin{array}{c}10^{7} \\
0.2 \mathrm{ml}\end{array}$} & Kumamoto & $\overline{21}$ & $126^{-}$ & 30 & 23.8 & 54 & 2.6 \\
\hline & Hawaiian & 20 & 120 & 25 & 20.8 & 54 & 2.7 \\
\hline & Fukuoka & 20 & 120 & 19 & 15.8 & 32 & 1.6 \\
\hline & Keishicho & 24 & 144 & 34 & 23.6 & $7 \overline{2}$ & 3.0 \\
\hline & Total & 85 & 510 & 108 & 21.2 & 212 & 2.5 \\
\hline
\end{tabular}


\%並に平圴指数が全体の平圴より上位にめるのは，八ワ イ, 警視庁, 熊本の順で, とてでも福岡株は下位であつ た。更に $10^{7}$ では, 熊本, 警視庁, 八ワイが全体の平均 指数より上位を示し，福岡は下位でまつた。而して上位 の 3 株はいずれの場合も，僅少の差で優劣を附し難い程 であつた。

上記の如く Leproma の拡がりと菌の体内分布から見た 4株の鼠瀨菌の Virulence について云えば，熊本，ハワ イ, 警視庁の 3 株間には, 特に著しい差がなく, 福風株 は発症度站に菌の分布に扔いて，かなり劣勢であつた。 この様に独り福岡株が劣つていたてとは, 先の接種菌量 の項に示された如く, 第 2 次接種時, 既にとの福岡株で は, $1 \mathrm{ml}$ 当りの菌数が他の菌株にくらべて甚だ少量であ つたととに起因するのではなかららかとも思われる。然 乙菌の乳刜を作る場合には細心の注意を払つて $3 〜 5$ 汇 から Lepromaを摘出, 脂肪組織を厳密に除去して科量 しているにも拘らず，福岡株のみとのように菌数の尠い ことは結局菌増殖力の弱いととを物語つているよらにも 考えられる。との菌数との関係については，更に機会を 得て検討したいと思ら。

\section{II 接種部位とその菌量}

鼠瀨病巣の好発部位は, 皮下の鬆柾な結合組織站に淋 巴腺であるが, 又内膕殊に脾, 肝など網内系組織に富む 㖑器にも屡々顕著な病変が現われる。従つて，かような 組織へ直接に適量の菌を定着せしめることが，発症を早 めるに最適でめろう。而して, その病変が肉眼的にも確 実に, 且容易化判定出来るととが，望ましい条件でめ る。

鼠瀨菌は, マウスのいずれの部位へ接種しても,よく 発症するが，通常行われている接種法は皮下注射であ る。然し, 目的によつては, 腹腔, 睪丸実質, 静脈, 前 眼房, 脳膜下等への接種法が試みられている。著者は, 乙れ等の接種法の中から, 手技が比較的簡単確実で, 判 定に便利な皮下接種, 腹腔接種, 静脈内接種を選び, こ の三者について発症の速度, 判定の確実, 且容易さを目 標として比較を行らととにした。

\section{皮下注射法}

皮下組織と云つても，背部，下腹部，腋下など，その 部位に依つて組織抵抗性或は鼠瀨肉芽の発症に適応する 条件が必ずしも同一ではない。これは，既に西村等がラ ットについて実験せる処である。そこで, この場合は発 症の速かなとと, Leproma 観察の容易な点, 菌の体表淋 巴腺分布等を考慮して，下榎部皮下注射に一定した。
下記の成績は, 前項の菌株選定実験に皮下注射法を採用 したので，との動物 457 匹に就いて，その成樍を援用検 討したものである。

1）接種菌量と局所に於ける攋腫の発生速度（第 1 2 表参照)

比較的澧厚な $10^{2}$ から極めて稀薄な $10^{8}$ まで数段階に 亘る菌液を接種した局部の発症状態即ち肉眼的に確実に 瀨腫を認め得るのは, 各菌株を通じ大体下記の様でめつ た。

$$
\begin{array}{ll}
10^{2} & 0.2 \mathrm{ml} \cdots \cdots \cdots .30 \sim 60 \text { 日 } \\
10^{4} & 0.2 \mathrm{ml} \cdots \cdots \cdots \cdot 60 \sim 90 \text { 日 } \\
10^{6} & 0.2 \mathrm{ml} \cdots \cdots \cdots .90 \sim 120 \sim 150 \text { 日 } \\
10^{7} & 0.2 \mathrm{ml} \cdots \cdots \cdots \cdot 120 \sim 150 \sim 180 \text { 日 } \\
10^{5} & 0.2 \mathrm{ml} \cdots \cdots \cdots \cdot \cdots \cdot 150 \text { 日以上 }
\end{array}
$$

此の様に, $10^{2} \sim 10^{4}$ では, 注ぼ 3 ケ月以内で確実に発 症させるととが出来るが, $10^{6}$ 以上では 90〜180 日を要 するから，乙の様な稀薄な菌液を用いるととは, 短い期 間内に判定を下す上から適当でないととが判る。結局, との成績から見れば， $10^{2} \sim 10^{4}$ のものを用いるのが良い と思ら。

\section{2) 局所以外の病変}

下腹部皮下接種の場合は，皮下の淋巴腺殊に鼠踫腺及 び腋窝腺が最も強く侵され, 肉眼的には腫浐, 結節, 壊 死が認められる。又長期経過の場合には, 内葴殊に脾, 肝, 肺に結節病栄を作るものが多い。然しこの様な肉眼 的病変は, 具体的にその程度を表わす客観性の出る記戴 法がなかなか团難で，てれ依つて判定の基凖を立てる ととは, 至難である。

3）体内の菌分布（第 $3 ， 4$ 表参照）

各菌侏の Virulence 比較の項で既に述べた样に，皮下 注射では表在淋巴腺に最も多く,内葴には甚で尠い。た だし濃厚な乳剤を接種した場合には，初期に於いて内垭 にも頻回菌を証明するととが出来る。

要するに皮下接種では, $10^{2} \sim 10^{4}, 0,2 \mathrm{ml}$ で局所に Leproma か短期間に発生し, 且つ体表淋巴腺には，10 ${ }^{2}$ で大部分に， $10^{4}$ では約半数に菌を証明し，てれ等はそ の程度を具体的に記載することが出来る。但し淋巴腺及 び内臓の肉眼的変化をとらえることは, 短期間の観察で は困難である。

\section{腹腔内注射法}

ての方法については，146 匹のマウス NA1 系を使用 し， 2 回実験を繰返した。即ち第一次実験では $\times 50$, 及 び $10^{2}$ 乳戍を $0.2 \mathrm{ml}$ 注射後, 30 日〜 150 日に亘り, 毎月 解剖，肉眼的变化と菌の分布について調べ第 2 次実験で 
Table 5 Macroscopic Findings of the Viscera of Animals inoculated intraperitoneally

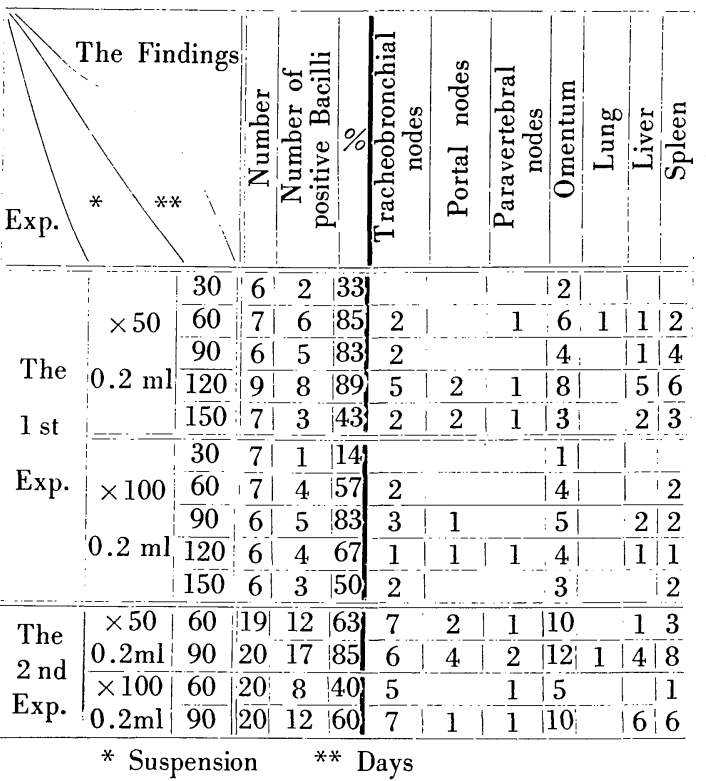

は，同様に $\times 50$ 及び $10^{2}$ 乳㓝接種後 60 日と 90 日に解剖し た。この場合皮下注射よりも，接種菌量を多量に用いた のは我等の彷来の経験から見て，少量の菌を接種したの
では，2〜3 ケ月で確実に内歲病巣を作り難いととを知 つていたからである。

1) 接種菌量と肉眼的病変の発生時期站びに必発臟器 (第 5 表)

第 1 , 第 2 実験とも濃厚な 50 倍液接種の方が強い病変 を現わした。経過別にみると，30日で肉眼的に明らかに 鼠瀨病采をみたものは極めて眇いが，60日〜90日〜120 日と日のたつにつれて顕著となつた。然しとの表では 150日の例は却つて減少を示した。各器官を通し最も准々 病変の現われるのは大網で，とれに次ぐは気管支淋巴腺 及び脾灆でむる。大網は灰白半透明の小結節が密発し， 気管支腺は腫大と結節が現われ，脾臟も亦多くの場合腫 大して結節を密発した。肝臓も顕著な病気では小結節密 発, 褪色, 実質脆弱化が見られた。肺瀻には肉眼的病変 を示すとと一般に想く，漸く 2 例に於いて，半透明灰白 色の小結節少数を認めたに過ぎない。

これを要するに全臓器を通じ, 大網が最も良く病変を 現わしたが，然しとれとても必発とは云い難く，第 1 次 実験では $\times 50$ 夜, $0.2 \mathrm{ml}$ 接種後 60 日〜 120 日で 22 匹中 18 匹，第 2 次実験では，39 匹中 22 匹に認めた程度でめつ た。そして $10^{2}$ 液接種組では，一層少数でめつた。

2）腹㖟内注射に依る菌の体内分布（第 6,7 表参照）

Table 6 Distribution of Bacillua after Intraperitoneal Inoculation

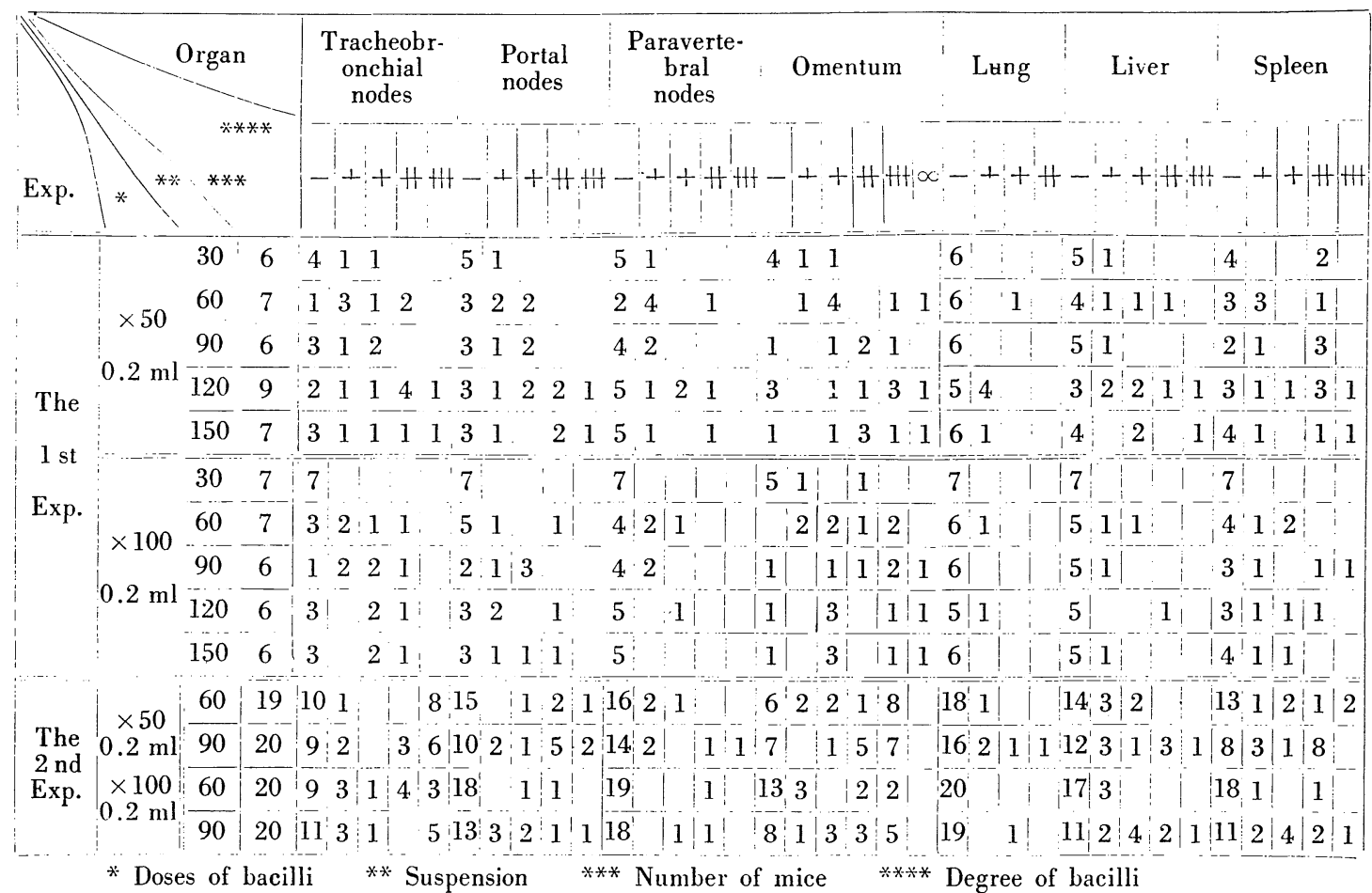


'lahle 7 Index of Bacillus Distrihution after Intraperitoneal Inoculation

\begin{tabular}{|c|c|c|c|c|c|c|c|c|c|c|c|c|c|c|c|c|c|c|c|c|c|}
\hline & & \multicolumn{2}{|c|}{ Organ } & \multicolumn{3}{|c|}{$\begin{array}{l}\text { Tracheobro- } \\
\text { nchial nodes }\end{array}$} & \multicolumn{2}{|c|}{$\begin{array}{l}\text { Portal } \\
\text { nodes }\end{array}$} & \multicolumn{3}{|c|}{$\begin{array}{c}\text { Paravertebral } \\
\text { nodes }\end{array}$} & \multicolumn{2}{|c|}{ Omentum } & \multicolumn{2}{|c|}{ Lung } & \multicolumn{3}{|c|}{ Liver } & \multicolumn{3}{|c|}{ Spleen } \\
\hline & * & \multicolumn{2}{|c|}{$* * * *$} & 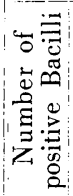 & $\begin{array}{l}\frac{\ddot{Q}}{E} \\
\stackrel{\Xi}{E} \\
\stackrel{E}{E}\end{array}$ & 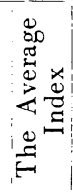 & 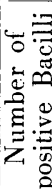 & 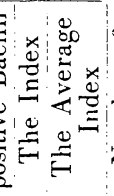 & 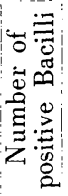 & 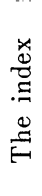 & 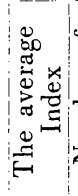 & 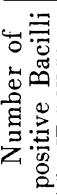 & 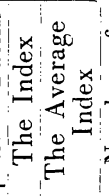 & 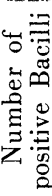 & 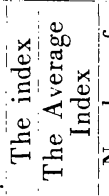 & 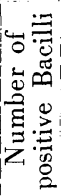 & 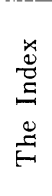 & 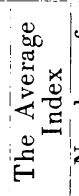 & 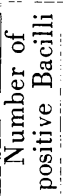 & 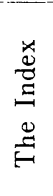 & 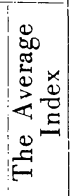 \\
\hline \multirow{10}{*}{ The } & \multirow{5}{*}{$\begin{array}{c}\times 50 \\
0.2 \mathrm{ml}\end{array}$} & 30 & 6 & 2 & 3 & 0.5 & 1 & $1,0.17$ & 1 & 1 & 0.17 & 2 & $3,0.50$ & 0 & 00.00 & 1 & 1 & 0.17 & 2 & 6 & 1.00 \\
\hline & & 60 & 7 & 6 & 9 & 1.30 & 4 & 60.86 & 5 & 8 & 1.14 & 7 & 182.57 & 1 & 20.29 & 3 & 6 & 0.86 & 4 & 6 & 26 \\
\hline & & 90 & 6 & 3 & 5 & 0.83 & 3 & 50.83 & 2 & 2 & 0.33 & 5 & 162.67 & 0 & 00 & 1 & 1 & 0.17 & 4 & 10 & 1.67 \\
\hline & & 120 & 9 & 7 & 19 & 2.11 & 6 & 151.67 & 4 & 9 & 1.00 & 7 & 252.78 & 4 & 40.44 & 6 & 13 & .44 & 6 & 16 & 1.78 \\
\hline & & 150 & 7 & 4 & 10 & 1.43 & 4 & 81,14 & 2 & 4 & 0.57 & 5 & 202.86 & 1 & 10.14 & 3 & 8 & 14 & 3 & 8 & 1.14 \\
\hline & \multirow{5}{*}{$\begin{array}{r}\times 100 \\
0.2 \mathrm{ml}\end{array}$} & 30 & 7 & 7 & 0 & 0.00 & 0 & 00.00 & 0 & 0 & 0.00 & 2 & 40.57 & 0 & 00.00 & 0 & 0 & 0.00 & 0 & 0 & 0.00 \\
\hline & & 60 & 7 & 4 & 7 & 1.00 & 2 & 40.57 & 3 & 4 & 0.57 & 7 & 172.43 & 1 & 10.14 & 2 & 3 & 0.43 & 3 & 5 & 0.71 \\
\hline & & 90 & 6 & 5 & 9 & 1.50 & 4 & 71.17 & & 2 & 0.33 & 6 & 183.00 & 0 & 00.00 & 1 & 1 & .17 & 3 & 8 & .33 \\
\hline & & 120 & 6 & 3 & 7 & 1.17 & 3 & 50.83 & 1 & 2 & 0.33 & 5 & 152.50 & 1 & 10.17 & 1 & 3 & 0.50 & 3 & 6 & .00 \\
\hline & & 150 & 6 & 3 & 7 & 1.17 & 3 & 61.00 & 0 & 0 & 0.00 & 6 & 142.33 & 0 & 0.00 & 1 & 1 & 0.17 & 2 & 3 & .50 \\
\hline \multirow{4}{*}{$\begin{array}{l}\text { The } \\
2 \text { nd } \\
\text { Exp. }\end{array}$} & \multirow{2}{*}{$\begin{array}{l}\times 50 \\
0.2 \mathrm{ml}\end{array}$} & 60 & 19 & 9 & 33 & 1.74 & 4 & 120.63 & 3 & 4 & 21 & 13 & 412.16 & 1 & & 5 & 7 & 37 & 6 & 16 & .84 \\
\hline & & 90 & 20 & 11 & 35 & 1.75 & 10 & 231.15 & 4 & 9 & 0.45 & 13 & 452.25 & 4 & $\mid \begin{array}{lll}7 & 0.37\end{array}$ & 8 & 18 & 0.90 & 12 & 29 & 1.45 \\
\hline & \multirow{2}{*}{$\times 100$} & 60 & 20 & 11 & 29 & 1.44 & 2 & 50.25 & 1 & 3 & 0.15 & 7 & .17 & 0 & 00 & 3 & 3 & 15 & 2 & 4 & 0 \\
\hline & & 90 & 20 & 9 & 25 & 1.25 & 7 & 140.70 & 2 & 5 & 0.25 & 12 & 361.80 & 1 & 10 & 9 & 20 & 1.00 & 9 & 20 & .0 \\
\hline
\end{tabular}

前記のマウスに就い它淋巴腺（気管支，肝門腺，腰部 腺, 大網) と, 黹器 (肺, 肝, 脾) に於ける菌の分布度 を調べた。標本の作り方は総て皮下注射の場合と同様に した。成績は表の通りで，第 1 ，第 2 次実験を通じ肉眼 的病変を認めないるのに於いても，塗抹標本中に菌を見 出した例が可成り希つて, 淋巴腺各藏器ともその陽性数 は肉眼的変化に比して一段と高率を示したが，大体に於 いて, 臓器例の成績は肉腿的所見と一致し, 陽性数と平

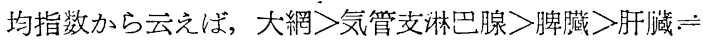
肝門腺>脊柱腺>肺臓の順序でせつた。そして最高の大 網に於ても60日〜120日の経過で全例に菌を証明すると 云らわけにはいかなかつた。

以上の如く，榎腔内注射では，50倍の如き極めて濃厚 な菌癄を接種しても病单必発の臟器を見出し難く, 又検 鏡でも大網に於いてさえ100\%に菌を証明出来なかつた。 此の様な成績から考えると，腹腔内注射法では，よ注ど 濃厚な菌夜を用いない限り，2〜3ケ月で全例に発症せ しめることはさづかしく, 又との判定法も肉眼的変化,
菌の分布所見を併せ，しかも多数のマウスを使用して， その平均值を求めるような方法でなければ，正皓を期し 難いように思われる。

\section{静眽内注射法}

この方法で濃厚な乳㓩を用いると，エムボリ一を起す 恐れがめるので， $10^{2}$ 液， $0.2 \mathrm{ml}$ 尾静脈から注射すると とにした。用いたマウスの数は，NA1-20匹である。成 績は第 8 表の通り。

肉眼的に定型的病变の認められたのは, 60 日目で, 朋 臟, 脾臟共に 2 例づつ, むとの 1 例は腫脤だけであつ た。90日では脾に小結節病单を示したるの4例，肝には 2 例でめつたが，単に腫大せるのみの例が各 1 例多つ た。淋怘腺には变化尠く, 腰部腺, 肝門腺の腫大したも の各・1 例にすぎなかつた。

菌分布は肝臓，脾臟，気管支淋巴腺が最も顕著であつ て, 肉眼的病変の無いものにも緊々見出した。従つて, 菌分布度は肉眼的变化よりも一層高率でせつた。然し， 病変必発臓器のないととは, 腹腔接種の場合と同様でも, 
Table 8 The Bacillus Distribution and Macroscopic Findings after Intravenous Injection

\begin{tabular}{|c|c|c|c|c|c|c|c|c|c|c|c|c|c|c|c|c|c|c|}
\hline 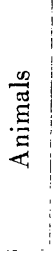 & 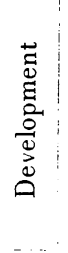 & 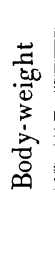 & 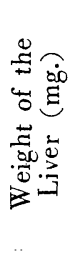 & 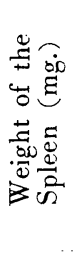 & Visceral Changes & 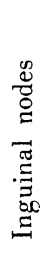 & 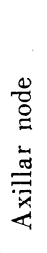 & 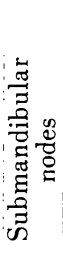 & 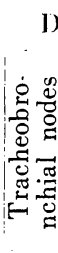 & 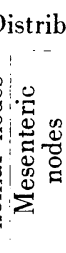 & $\begin{array}{l}\frac{0}{4} \\
0 \\
0 \\
0 \\
\overrightarrow{0} \\
\vdots \\
0 \\
0\end{array}$ & 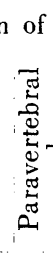 & & 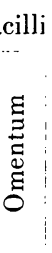 & $\stackrel{\infty^{\infty}}{\Xi}$ & $\stackrel{\overrightarrow{0}}{: \vec{n}}$ & $\frac{5}{0}$ & 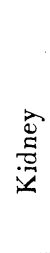 \\
\hline 1 & \multirow{10}{*}{$\begin{array}{c}2 \\
(\mathbf{M} .)\end{array}$} & 19 & 995 & 35 & \multirow{5}{*}{$\begin{array}{l}\text { liver ; slightly anemia, spleen; } \\
\text { swoleen with many tubercles }\end{array}$} & - & - & - & - & - & - & - & & - & - & - & - & - \\
\hline 2 & & 21 & 726 & 45 & & - & - & - & - & - & - & - & & - & - & - & - & - \\
\hline 3 & & 20 & 1395 & 435 & & - & - & - & 一 & - & - & - & & - & - & Ht & H & - \\
\hline 4 & & 24 & 1122 & 155 & & - & - & + & - & - & - & - & & - & - & + & $\perp$ & - \\
\hline 5 & & 22 & 1025 & 42 & & - & - & - & - & - & - & - & & - & - & $\perp$ & - & - \\
\hline 6 & & 27 & 1575 & 380 & \multirow[t]{2}{*}{$\begin{array}{l}\text { liver, speen; swollen with } \\
\text { many_tubercles }\end{array}$} & - & - & - & - & - & $\perp$ & $\perp$ & & - & - & Ht & $H$ & $\perp$ \\
\hline 7 & & 25 & 1350 & 370 & & - & - & - & - & - & - & - & & - & - & - & - & - \\
\hline 8 & & 23 & 1380 & 285 & $\begin{array}{l}\text { liver \& sp } \\
\text { swollen }\end{array}$ & - & - & - & - & - & - & - & & - & - & $\perp$ & - & $\perp$ \\
\hline 9 & & 24 & 1485 & 125 & & - & 一 & - & - & - & - & - & & - & - & - & H & - \\
\hline 10 & & 24 & 1325 & 178 & & - & - & - & - & - & $\perp$ & - & & - & - & - & - & - \\
\hline 11 & \multirow{10}{*}{ (M.) } & 23 & 1360 & 60 & liver; slightly swollen & - & - & - & $\perp$ & - & - & - & & - & - & - & - & - \\
\hline 12 & & 20 & 790 & 80 & ny tubercles & 一 & - & - & - & - & - & - & & - & - & + & H & - \\
\hline 13 & & 25 & 1200 & 120 & & - & - & + & - & - & - & - & & + & - & + & - & - \\
\hline 14 & & 21 & 1100 & 90 & & - & - & - & $\perp$ & - & - & - & & - & - & $\perp$ & - & - \\
\hline 15 & & 23 & 1100 & 140 & & - & - & - & + & - & - & + & & - & - & H & - & - \\
\hline 16 & & 25 & 1100 & 360 & $\begin{array}{l}\text { liver \& spleen swollen with } \\
\text { many tubercles; }\end{array}$ & $\perp$ & $\perp$ & - & - & H & - & H & & - & - & Ht & H & - \\
\hline 17 & & 28 & 1260 & 200 & liver; tubercles & + & - & - & $\perp$ & - & $\perp$ & - & & - & - & $H$ & + & - \\
\hline 18 & & 24 & 990 & 120 & spleen; small tubercles & - & - & - & - & - & - & - & & - & - & $\perp$ & $\mathrm{Ht}$ & - \\
\hline 19 & & 26 & 1000 & 180 & & - & - & - & - & - & - & - & & - & - & + & $\perp$ & - \\
\hline 20 & & 22 & 1000 & 190 & $\begin{array}{l}\text { spleen; } \\
\text { nodes; sv }\end{array}$ & - & - & $\perp$ & - & - & HI & - & & - & - & - & - & - \\
\hline
\end{tabular}

る。我々はとの静脈内注射法では臟器の病変と菌分布が

一層顕著であるととを期待したが,結果はこれに区した。
さて Screening Test には，どの様な接種法が適当であ るか。上記三つの方法についてとれを比較表示してみた。

\begin{tabular}{|c|c|c|c|}
\hline 位 - 別 & 皮 下 接 種 & 榎 腔 接 種 & 静 脈 内 接 種 \\
\hline 注射法の難易 & 容易 & 容 & 熟練を要する \\
\hline 接 種 菌 量 & $10^{2}-10^{4}, 0.2 \mathrm{ml}$ & $\times 50-10^{2} \quad 0.2 \mathrm{ml}$ & $\times 100 \quad 0.2 \mathrm{ml}$ \\
\hline 発症までの日数 & $\begin{array}{c}10^{2}, 0.2 \mathrm{ml}=1 \sim 2 \text { 月 } \\
10^{4}, 0.2 \mathrm{ml}=3 \text { 月 }\end{array}$ & $\begin{array}{ll}\times 50, & 0.2 \mathrm{ml}=3 \text { 月 } \\
10^{2}, & 0.2 \mathrm{ml}=4 \text { 月 }\end{array}$ & $\begin{array}{c}10^{2} \quad 0.2 \mathrm{ml} \\
3 \text { 月 } ~\end{array}$ \\
\hline 肉 眼 的病 䉓 & 局 所 & 約 $50 \%$ & 約 $30 \%$ \\
\hline 菌 体 内分布 & 皮下， & $\begin{array}{l}\text { 大網,気管支腺, 脾, } \\
\text { 肝に多し }\end{array}$ & 肝, 脾に最多 \\
\hline 確実 & $\begin{array}{l}\text { 局芹の Leproma の } \\
\text { 因眼的観察 }\end{array}$ & $\begin{array}{l}\text { 大網, 脾, 肝の病変 } \\
\text { 観察と菌分布調へ }\end{array}$ & $\begin{array}{l}\text { 年, 脾の病変と菌 } \\
\text { 分布の検索 }\end{array}$ \\
\hline
\end{tabular}




\section{総括}

1）鼠顆菌熊本株，八ワイ株，警視庁株，福闭株の 4 株に就いて，純系マウス皮下注射法に依つて，その Virulence を比較した所, 福岡株のみ稍々弱く, 他の 3 株は殆んぞ闰等の発症力を示した。

2）注射部位に就いて，発症が早く，確実且簡便に判 定出来るととを目標として, 皮下, 嗄点, 静脈の 3 方 法について検討した所皮下注射法は，早期に局所へ Leproma を必発し，肉眼的に容易に確実に観祭でき た。

腹腔注射, 静脈内注射では，早期に病变必発の睵器を 見出し難く, 比較的長い経過後に全臓器に病变を発生 するので，その判定法も菌分布指数で表わし得る外 は，肉眼的病変を客観性のある具体的な指標に基い て，表示するととが困難であつた。

3) 接種菌量は皮下注射では $10^{2} \sim 10^{4}$ Leproma 一乳
剤 $0.2 \mathrm{ml}$ で，2〜 2 ケ月で発症するが， $10^{6}$ 〜 $10^{8}$ と菌 量が減少するに従つて，発症に長時日を要する。腹腔 内では $\times 50$ 乳剤 $0.5 \mathrm{ml}$ の大量を接種しても $3 \sim 4$ ケ月 を要する。静脈内では, $10^{2}$ 液 $0.2 \mathrm{ml}$, 接種 3 ケ月後 には約 $30 \%$ 臟器に肉眼的病変を認めた程度であるか ら，全部に病巣を証明するまでには更に長期の観察を 必要とするであろら。

以上の実験成績より見て，菌株は同等の Virulence を 有する 3 株の内，国際性のあるハワイ株を選び，皮下へ $10^{2} \sim 10^{4}$ 夜 $0.2 \mathrm{ml}$ 接種して 3 ケ月間観察するのが最も適 当であると思ら。

本実験は交部省科学研究費並に大阪結核研究会の援助 に依る。終りに佐谷, 谷村両名誉教授の御指導と御鞭䪋 を深謝いたします。

(文献後掲) 